\title{
Implementasi Kegiatan Sains Melalui Konstruktivisme Inkuiri Dengan Eksperimen Untuk Meningkatkan Kemampuan Kognitif Anak
}

\author{
Libri Rizka Puri Windarta \\ Libririzka16@gmail.com \\ TK ABA Sumberadi
}

\begin{abstract}
The purpose of this study was to find out how the implementation of science play activities through the construction of inquiry with experimental methods to improve children's cognitive abilities. This research is a classroom action research with research subject group B children in TK ABA Sumberadi, which consists of 24 children with 13 girls and 11 boys. The object of this research is cognitive abilities that will be enhanced through inquiry constructivism through experimental methods in science activities. Data gathering techniques used are observation and documentation. The data analysis technique used is quantitative descriptive. The results of this study have shown an increase in cognitive abilities in group B children in TK ABA Sumberadi after using science activities. This can be proven by an increase from cycle to cycle, from pre-action, cycle I to cycle II, the average cognitive ability of pre-action children is $50 \%$ with unfavorable criteria increasing to $65.3 \%$, sufficient criteria in cycle I and increased again after the implementation of the second cycle which is $86.1 \%$ with good criteria.
\end{abstract}

Keywords : implementation, Constructivism of Inquiry, Experiments, Cognitive

\begin{abstract}
Abstrak
Tujuan penelitian ini adalah untuk mengetahui bagaimana implementasi kegiatan bermain sains melalui konstruksi inkuiri dengan metode eksperimen untuk meningkatkan kemampuan kognitif anak. Penelitian ini merupakan penelitian tindakan kelas dengan subjek penelitian anak-anak kelompok B di TK ABA Sumberadi, yang terdiri dari 24 anak dengan 13 anak perempuan dan 11 anak laki-laki. Objek penelitian ini adalah kemampuan kognitif yang akan ditingkatkan melalui konstruktivisme inkuiri melalui metode eksperimen pada kegiatan sains. Teknik pengumpulan data yang digunakan adalah observasi dan dokumentasi. Teknik analisis data yang digunakan adalah deskriptif kuantitatif. Hasil penelitian ini telah menunjukkan adanya peningkatan kemampuan kognitif pada anak kelompok B di TK ABA Sumberadi setelah menggunakan kegiatan sains. Hal tersebut dapat dibuktikan dengan adanya peningkatan dari siklus ke siklus yaitu dari pra tindakan, siklus I sampai ke siklus II yaitu nilai rata-rata kemampuan kognitif anak pra tindakan adalah 50\% dengan kriteria kurang baik meningkat menjadi $65,3 \%$ kriteria cukup pada siklus I dan meningkat lagi setelah pelaksanaan siklus II yaitu menjadi $86,1 \%$ dengan kriteria baik.
\end{abstract}

Kata Kunci : implementasi, Konstruktivisme Inkuiri,Eksperimen, Kognitif 


\section{PENDAHULUAN}

Anak usia dini merupakan aset masa depan yang harus distimulus perkembangannya sejak dini, karena anak usia dini merupakan usia emas yang perkembangan dan pertumbuhannya akan berkembang dengan pesat jika di stimulasi dengan baik. Stimulasi yang dilakukan sesuai tahap perkembangan anak agar perkembangan anak akan berkembang secara maksimal.

Kegiatan belajar mengajar di sekolah tentunya memberikan andil yang besar dalam proses perkembangan dan pertumbuhan anak oleh karena itu sebaiknya pendidik memberikan kegiatan yang sesuai bagi proses pertumbuhan anak dengan metode yang menarik agar anak antusias terhadap kegiatan main yang diberikan oleh guru. Berdasarkan observasi yang dilakukan oleh peneliti, di lembaga tersebut sudah mengenalkan kegiatan sains bagi anak usia dini untuk meningkat, namun metode yang digunakan guru masih menggunakan metode penugasan yaitu menggunakan lembar kerja anak sehingga anak kurang antusias terhadap kegiatan yang diberikan. Dengan masalah tersebut maka perkembangan anak akan berkembang tidak maksimal sesuai dengan tahapannya. Maka guru membutuhkan suatu metode yang digunakan dalam proses pembelajaran, sehingga anak akan tertarik dalam kegiatan mainnya, oleh karena itu peneliti menggunakan metode praktek langsung dalam kegiatan terutama bermain sains.

Setelah peneliti menggunakan konstruksi inkuiri dengan metode eksperimen pada kegiatan sains, maka akan terlihat keefektifan kegiatan sains melalui metode eksperimen untuk meningkatkan aspek perkembangan anak terutama aspek kognitif anak.

\section{Kegiatan Sains}

Anak usia dini memiliki sifat yang unik karena selalu ingin tahu apa yang ada di lingkungan sekitarnya. Sebaiknya rasa ingin tahu tersebut dapat dimanfaatkan oleh orang dewasa untuk mengarahkan mereka ke dalam pencarian informasi dalam rangka menemukan jawaban dari pertanyaan yang mereka ajukan sendiri. Dalam pembelajaran sains, tentu saja hal ini dapat dijadikan salah satu kondisi yang menguntungkan bagi guru karena guru dapat dengan mudah mengarahkan anak-anak ke dalam kegiatan belajar sains.

Suci utami berpendapat (Putri 2019) sains bagi anak usia dini bukanlah hanya sekedar kumpulan fakta, melainkan melibatkan aktivitas mengobservasi tentang apa yang terjadi, mengklasifikasikan atau mengorganisasikan informasi, 
memprediksi tentang apa yang akan terjadi, menguji prediksi melalui kegiatan sains yang terbimbing serta merumuskan kesimpulan.

Menurut yuliani (Yulianti 2010) bermain sains adalah salah satu kegiatan atau cara yang dapat digunakan pendidik untuk meningkatan kemampuan kognitif anak usia dini. Bermain sains atau kegiatan sains ini juga sudah termasuk dalam kurikulum yang menjelaskan tentang pendekatan pembelajaran pada pendidikan Taman Kanak-Kanak termasuk pembelajaran Materi Sains dilakukan dengan berpedoman pada program kegiatan yang telah disusun, sehingga seluruh pembiasaan dan kemampuan dasar yang ada pada anak dapat dikembangkan dengan sebaik-baiknya dan optimal.

Metode-metode yang di gunakan untuk mengembangkan kognitif anak (Roza 2012) yaitu metode yang mampu menggerakkan anak agar dapat berfikir, menalar, mampu menarik kesimpulan, dan membuat generalisasi. Caranya adalah dengan memahami lingkungan di sekitarnya, mengenal orang dan benda-benda yang ada, 16 memahami tubuh dan perasaan mereka sendiri, melatih memahami untuk mengurus diri sendiri. Selain itu melatih anak menggunakan bahasa untuk berhubungan dengan orang lain, dan melakukan apa yang dianggap benar berdasarkan nilai yang ada dalam masyarakat. Metode yang di pilih untuk meningkatkan sains anak adalah metode yang dapat menggerakkan anak untuk meningkatkan motivasi, rasa ingin tahu, dan mengembangkan imajinasi. Dalam mengembangkan sains anak metode yang dipergunakan mampu mendorong anak mencari dan menemukan jawabannya, membuat pertanyaan yang membantu memecahkan, memikirkan kembali, membangun kembali, dan menemukan hubungan-hubungan baru.

Penelitian ini diharapkan dapat menyumbangkan manfaat bagi berbagai pihak, yaitu bagi peserta didik dan guru manfaat bagi peserta didik yaitu diharapkan dengan diadakannya penelitian ini kemampuan kognitif anak akan berkembang setelah diberikan kegiatan-kegiatan sains yang sebelumnya diberikan oleh guru kelas namun dengan metode yang berbeda. Sedangkan bagi guru adalah dapat mengetahui metode apa yang tepat untuk diterapkan dalam pemberian pembelajaran untuk mengembangkan kemampuan kognitif anak melalui kegiatan sains. Harapan dari peneliti adalah dengan adanya penelitian ini pengetahuan guru untuk memberikan kegiatan sains kepada anak bertambah

\section{Konstruktivisme Inkuiri}


Nur Hamzah berpendapat (Nur Hamzah 2015) pembelajaran pada anak usia dini umumnya dilandasi oleh dua teori belajar yaitu behaviorisme dan konstruktivisme. Behaviorisme adalah aliran psikologi yang memandang manusia belajar dipengaruhi oleh lingkungan. Belajar sendiri mempunyai arti perubahan tingkah laku yang terjadi melalui proses stimulus dan respon. Oleh sebab itu lingkungan yang sistematis, teratur dan terencana dapat memberikan pengaruh yang baik pada anak. Sedangkan konstruktivisme merupakan teori belajar Konstruktivisme merupakan teori yang memandang bahwa peserta didik mampu membangun pengetahuannya sendiri berdasarkan pengalaman belajarnya. Jean Piaget seorang ilmuwan yang mengawali penelitian terkait teori perkembangan kognitif menjelaskan bahwa seorang mampun membangun pengetahuan melalui kegiatan asimilasi dan akomodasi. Proses asimilasi dan akomodasi dalam konteks kontruktivisme menunjukkan bahwa pandangan kontruktivisme lebih menekankan pada proses pengembangan atau pendalaman pengetahuan yang dilakukan secara aktif oleh anak sama halnya dengan pengenalan sains kepada anak lebih ditekankan kepada proses belajar anak. Hal ini berarti dalam proses pembelajaran, pendidik harus mampu merancang kegiatan yang melibatkan siswa secara aktif dan dominan dalam mengeksplorasi kegiatan yang diberikan. Berkenaan dengan hal itu, pemahaman tentang teori belajar konstuktivistik yang dikembangkan oleh Piaget, bahwa pengetahuan akan bermakna jika dicari dan ditemukan sendiri oleh peserta didik. Sejak usia dini setiap anak berusaha mencari dan mampu mengembangkan pengetahuannya sendiri melalui skema yang ada dalam struktur kognitif (Hamruni 2012).

Anak usia dini memiliki sifat yang unik karena selalu ingin tahu apa yang ada di lingkungan sekitarnya. Rasa ingin tahu tersebut dapat dimanfaatkan oleh orang dewasa untuk mengarahkan mereka ke dalam pencarian informasi dalam rangka menemukan jawaban dari pertanyaan yang mereka ajukan sendiri. Dalam pembelajaran sains, tentu saja hal ini dapat dijadikan salah satu kondisi yang menguntungkan bagi guru karena guru dapat dengan mudah mengarahkan anakanak ke dalam kegiatan belajar yang bersifat investigasi sesuai dengan prinsipprinsip konstruktivisme dan inkuiri (Putri 2019). Inquiry berasal dari kata "to inquire" yang berarti ikut serta. Atau terlibat,dalam mengajukan pertanyaanpertanyaan, mencari informasi, dan melakukan penyelidikan (Suryani and Agung 2012). Strategi pembelajaran inquiry adalah rangkaian kegiatan pembelajaran 
yang menekankan pada proses berpikir secara kritis dan analitis untuk mencari dan menemukan sendiri jawaban dari suatu masalah yang dipertanyakan. Proses berpikir itu sendiri biasanya dilakukan melalui tanya jawab antara guru dan peserta didik (Hamdani 2011).

Terkait kegiatan belajar yang didasarkan pandangan konstruktivisme, inkuiri merupakan salah satu metode yang relevan dengan prinsip konstruktivisme karena metode ini memberikan kesempatan bagi peserta didik untuk terlibat dalam serangkaian kegiatan ilmiah yang membangun konsep. Bulba (2018) (Putri 2019) mengemukakan bahwa inkuiri diadopsi dari sebuah pendekatan investigasi dimana anak diberikan kesempatan untuk menyelidiki suatu masalah, mencari kemungkinan-kemungkinan solusi, melakukan observasi, mengajukan pertanyaan, menguji gagasan atau ide, serta berpikir kreatif dan melatih siswa menggunakan intuisinya. Lebih lanjut lagi bulba mengatakan bahwa penerapan inkuiri pada jenjang pendidikan tertentu yaitu anak usia dini menggunakan inkuiri terbimbing.

\section{Metode Eksperimen}

Metode eksperimen (Khadijah 2016) adalah cara penyajian pelajaran, dimana siswa melakukan percobaan dengan mengalami dan membuktikan sendiri sesuatu yang dipelajari. Metode eksperimen adalah percobaan tentang sesuatu, dalam hal ini setiap anak bekerja sendiri-sendiri. Pelaksanaan lebih memperjelas hasil belajar, karena setiap anak mengalami dan melakukan kegiatan percobaan.

Metode eksperimen (Suryani and Agung 2012) adalah metode yang membuat siswa mengalami secara langsung proses pembelajaran dengan melakukan percobaan. Hal yang sama juga dijelaskan oleh Suryani, bahwa metode eksperimen adalah metode dimana siswa secara mandiri melakukan percobaan sebagai bentuk pembuktian dari sesuatu yang dipelajari. Metode eksperimen adalah cara memberikan pengalaman kepada anak di mana anak memberi perlakuan terhadap sesuatu dan mengamati akibatnya, misalnya, balon ditiup, warna dicampur, air dipanaskan, tanaman disirami atau tidak disirami, dan lainlain.

Metode eksperimen (Dimiyati Mujion 2010) adalah metode pemberian kesempatan kepada anak usia dini perorangan atau kelompok, untuk dilatih melakukan suatu proses atau percobaan. Metode eksperimen merupakan metode mengajar dalam penyajian atau penambahan materinya melalui percobaan atau mencoba sesuatu serta mengamati secara proses. 
Eksperimen (percobaan) yang dimaksud dalam hal ini bukanlah suatu proses rumit yang harus dikuasi anak sebagai suatu cara untuk memahami konsep tentang sesuatu hal ataupun penguasaan anak tentang konsep dasar eksperimen, melainkan bagaimana mereka dapat mengetahui cara atau proses terjadinya sesuatu, dan mengapa sesuatu dapat terjadi serta bagaimana mereka dapat menemukan solusi terhadap permasalahan yang ada dari pada akhirnya mereka dapat membuat sesuatu yang bermanfaat dari kegiatan tersebut (Mulyasa 2012).

Penggunaan teknik ini mempunyai tujuan agar anak-anak mampu mencari dan menemukan sendiri berbagai jawaban atau persoalan-persoalan yang dihadapinya dengan mengadakan percobaan sendiri. Juga anak dapat terlatih dalam cara berfikir yang ilmiah.

Langkah-langkah dalam pelaksanaan pembelajaran melalui metode eksperimen yaitu (Khadijah 2016): a) Menetapkan tujuan eksperimen, adapun tujuan eksperimen adalah untuk meningkatkan kemampuan kognitif anak b) Mempersiapkan alat dan bahan yang diperlukan, adapun alat dan bahan dalam kegiatan c) Menyiapkan tempat pelaksanaan eksperimen. d) Perhatikan keamanan dan kesehatan agar dapat mengahindari resiko. e) Perhatikan tata tertib atau disiplin, terutama dalam menjaga perlatan dan bahan yang akan digunakan serta mengalokasikan waktu. Berikan penjelasan tentang apa yang harus diperhatikan dan tahapan yang harus dilakukan oleh anak. Sebelum pelaksanaan eksperimen, guru memberikan prosedur yang harus diperhatikan dalam metode eksperimen.

Metode eksperimen sebagai sebuah langkah sistematis dalam pembelajaran memiliki langkah atau prosedur, sebagaimana yang dikutip oleh Rizema bahwa langkah metode eksperimen dilakukan dalam tiga tahapan yakni persiapan, pelaksanaan dan tindak lanjut serta dijelaskan sebagai berikut:Tahap persiapan terdiri darin1) Menentukan tujuan atau sesuatu apa yang perlu dibuktikan 2) Menyiapkan alat atau bahan yang dibutuhkan dalam proses percobaan. 3) Mempertimbangkan jumlah alat atau bahan dengan jumlah siswa. 4) Merancang dan menyiapkan kegiatan ataupun bahan yang aman agar tidak membahayakan dan merugikan. Kedua adalah tahap pelaksanaan 1) Siswa melakukan percobaan, saat tahap ini guru diharapkan mengamati proses yang dilakukan anak dan tetap memberikan motivasi pada anak. 2) Guru juga perlu memperhatikan seluruh proses. Terakhir adalah tahap lanjutan Tahapan ini dilakukan setelah pelaksanaan eksperimen. 


\section{Perkembangan Kognitif}

Perkembangan Kognitif merupakan dasar bagi kemampuan anak untuk berpikir. Hal ini sesuai dengan pendapat Ahmad Susanto (Susanto 2012) menjelaskan bahwa kognitif adalah suatu proses berpikir, yaitu kemampuan individu untuk menghubungkan, menilai, dan mempertimbangkan suatu kejadian atau peristiwa. Jadi proses kognitif berhubungan dengan tingkat kecderdasan (intellegence) yang menandai seseorang dengan berbagai minat terutama sekali ditujukan kepada ide-ide belajar.

Piaget (Suyadi 2010) mengatakan bahwa pengetahuan dapat diperoleh melalui eksplorasi, manipulasi, dan konstruksi secara elaboratif. Dalam perkembangan kognitif anak usia dini merupakan hasil proses dari asimilasi dan akomodasi. Asimilasi merupakan penyerapan informasi baru yang telah ada dalam struktur kognitif anak.Sedangkan akomodasi merupakan penyatuan informasi yang sudah ada dengan informasi baru sehingga memperluas informasi yang sudah ada dalam schemata/ cara padang anak.

Salah satu teori kognitif adalah teori dari Jean Piaget, secara garis besar Piaget mengelompokkan tahap-tahap perkembangan kognitif seorang anak menjadi empat tahapan yaitu sensorimotor, praoperasi, operasional konkret dan tahap operasi formal. Pada tahap sensorimotor lebih ditandai dengan pemikiran anak berdasarkan inderawinya, tahap praoperasi diwarnai dengan digunakannya simbol-simbol untuk menghadirkan suatu benda atau pemikiran khususnya penggunaan bahasa. Tahap operasi konkret ditandai dengan penggunaan aturan logis yang jelas. Tahap operasi formal ditandai dengan pemikiran abstrak, hipotesis, deduktif serta induktif.

Perkembangan kognitif anak usia 5-6 tahun berada dalam fase praoperasional dapat dikenali dengan kemampuan anak untuk melakukan kegiatan representasi mental yaitu, kemmampuan untuk menghadirkan benda, objek atau orang dan peristiwa secara mental. Ini berarti anak telah mempunyai kemampuan untuk membayangkan benda, objek, orang dan peristiwa di dalam pikirannya walaupun semuanya tidak hadir di depan anak. Kemampuan seperti ini disebut kemampuan berpikir secara simbolis, dan kemampuan ini akan muncul ketika anak bermain, anak sedang mengoperasikan kemampuan berpikir simbolis.

Tahapan perkembangan kognitif anak sudah baku dan saling berkaitan dalam setiap urutannya. Urutan tahapan tidak dapat ditukar atau dibalik karena 
tahap sesudahnya melandasi terbentuknya tahap sebelumnya. Akan tetapi, terbentuknya tahap tersebut dapat berubah-ubah menurut situasi seseorang. Perbedaan antara tahap sangat besar, karena ada perbedaan kualitas pemikiran yang lain. Meskipun demikian unsur dari perkembangan sebelumnya tetap tidak dibuang. Jadi, ada kesinambungan dari tahap ke tahap, walaupun ada juga perbedaan yang sangan mencolok (Suryana 2016).

\section{METODOLOGI}

Penelitian ini merupakan Penelitian Tindakan Kelas yang dimaksudkan untuk memberi informasi bagaimana tindakan yang tepat untuk meningkatkan kemampuan anak khususnya dalam bermain balok. Penelitian Tindakan Kelas bertujuan untuk meningkatkan kinerja guru serta hasil belajar anak didik. Dengan kata lain, PTK bertujuan bukan hanya mengungkapkan penyebab dariberbagai permasalahan yang dihadapi, tetapi yang lebih penting lagi adalah memberikan solusi yang berupa tindakan untuk mengatasi permasalahan pembelajaran tersebut (Suwandi 2009).

Selain itu menurut Arikunto (Arikunto and Suhardjono 2006) PTK dilakukan dengan tujuan memperbaiki/meningkatkan mutu praktik pembelajaran di kelas. Penelitian ini bertujuan untuk meningkatkan kemampuan kognitif melalui kontruktivisme inkuiri dengan eksperimen menggunakan kegitan sains pada kelompok B TK ABA Sumberadi. Seorang pakar Pendidikan mengemukakan bahwa "PTK bertujuan untuk memperbaiki mutu praktik pembelajaran dikelas. PTK dilakukan oleh guru atau penelitian untuk mencari solusi dalam memecahkan permasalahan yang terjadi dikelas yang dialami langsung dalam interaksi antara guru dengan anak yang sedang belajar secara lebih rinci.

Dalam pelaksanaan tindakan di dalam kelas, maka akan terjadi kolaborasi antara peneliti dengan guru yang merupakan hal yang sangat terpenting dalam penelitian. Dengan adanya kerjasama ini, maka secara bersama guru dan peneliti akan menggali dan mengkaji permasalahan nyata yang dihadapi peserta didik di lingkungan sekolah. Pilihan model kolaborasi ini dipandang tepat karena masalah yang diangkat dalam penelitian ini adalah masalah yang terjadi di kelompok B TK ABA Sumberadi yang jarang menggunakan metode praktek langsung dalam kegiatan sains yang disampaikan kepada anak, sehingga anak kurang tertarik untuk ikut terjun dalam pembelajaran sains.

Dalam proses tindakan yang dilakukan dalam penelitian ini diupayakan agar masalah yang terjadi di sekolah dapat diatasi sekaligus untuk meningkatkan 
pembelajaran di kelas tersebut. Sasaran Penelitian ini adalah 24 anak kelompok B usia 5-6 tahun di TK ABA Sumberadi. Teknik pengumpulan data penelitian ini menggunakan observasi dan dokumentasi, observasi dilakukan pada saat sebelum ada tindakan, untuk mengetahui perubahan kemampuan kognitif setelah mendapatkan kegiatan sains. Pada saat proses pembelajaran setelah ada tindakan, agar dapat diketahui mengenai peningkatan kemampuan kognitif anak ke arah positif sesuai dengan perkembangan yang diharapkan. Pada saat akhir dari proses pembelajaran, agar dapat diketahui bagaimana peningkatan kemampuan kognitif anak setelah dilakukan beberapa kali proses tindakan. Sedangkan dokumentasi dilakukan dengan cara mengambil foto siswa pada saat proses kegiatan sains dilaksanakan. Dokumentasi digunakan untuk memberikan gambaran secara nyata tentang tingkat kemampuan kognitif pada saat proses pembelajaran sains dilaksanakan dan untuk memperkuat data yang telah diperoleh pada saat penelitian dilakukan. Dokumen tersebut berupa foto yang memberikan gambaran secara konkrit mengenai kegiatan siswa. Foto-foto tersebut kemudian dikumpul menjadi sebuah portofolio.

Pengembangan instrumen penelitian ini menggunakan checklist dan domumentasi sedangkan lembar observasi digunakan sebagai pedoman untuk melakukan observasi ini berbentuk checklist. Check list merupakan alat observasi yang praktis untuk digunakan, sebab semua aspek yang akan diteliti sudah ditentukan terlebih dahulu. Observer tinggal memberi tanda ada atau tidak adanya dengan tanda cek $(\sqrt{ })$ tentang aspek yang diobservasi.

Check list merupakan alat observasi yang praktis karena semua aspek dapat diteliti, peneliti dalam penelitian ini berusaha memilih indikator yang ada dalam pengembangan indikator TK yang harus dicapai oleh anak kelompok B kemudian dikaitkan dengan indikator kemampuan kognitif anak.

Panduan observasi bertujuan untuk mendapatkan data yang berhubungan dengan pelaksanaan kegiatan pembelajaran sains. Data yang didapat dari observasi ini memberikan informasi tentang gambaran kemampuan kognitif anak dalam kegiatan sains. Adapun instrumennya terlampir dibawah.

Penilaian terhadap peningkatan kemampuan sains anak tersebut juga dilakukan dengan menggunakan skala penilaian. Skor peningkatan kemampuan kognitif yang digunakan adalah skor antara 1 sampai 3. Skor 1 jika anak belum dapat melakukan, skor 2 jika anak dapat melakukan namun masih di bawah 
bimbingan guru dan skor 3 jika anak bisa melakukannya sendiri. Keterangan lebih lanjut terdapat pada rubrik penilaian.

Pengembangan instrumen yang kedua adalah dengan dokumentasi, fotofoto yang digunakan untuk memberikan gambaran secara konkret tentang kegiatan yang dilakukan guru maupun anak pada saat pembelajaran berlangsung. Analisa data yang digunakan dalam penelitian ini menggunakan statistik deskriptif kuantitatif dengan persentase.

\section{HASIL DAN PEMBAHASAN}

Pelaksanaan tindakan merupakan realisasi dari pelaksanaan pembelajaran yang sudah disusun sebelumnya. Dalam penelitian tindakan kelas ini telah disusun dua siklus. Pada penelitian ini masing-masing siklus dilaksanakan tiga kali pertemuan, setiap pertemuan terdiri dari kegiatan pembuka, Kegiatan inti dan kegiatan penutup. Kegiatan sains diberikan pada saat kegiatan inti dan penilaian dengan observasi dilakukan oleh peneliti serta guru pada saat melakukan kegiatan sains yang telah direncanakan sebelumnya.

Setelah siklus I selesai, maka peneliti melakukan refleksi terhadap kegiatan sains yang dilakukan pada siklus I. peneliti melakukan refleksi kemudian peneliti akan melakukan penelitian berikutnya di siklus II, dalam siklus II kegiatan sains yang diberikan berbeda dengan siklus I namun dengan indikator yang sama.

Peningkatan kemampuan kognitif dapat dilihat dengan cara membandingkan data yang diperoleh dari pra penelitian dengan data setelah dilaksanakan siklus I. Berdasarkan data yang diperoleh peningkatan rata-rata kemampuan kognitif anak sebelum adanya tindakan data yang diperoleh pada kemampuan klasifikasi yaitu 58,3\% dan setelah ada tindakan 70,8\%. Pada kemampuan menghubungkan sebab-akibat hasilnya sebelum ada tindakan $50 \%$ dan setelah adanya tindakan 62,5\%, pada kemampuan memecahkan masalah hasilnya adalah sebelum adanya tindakan $41,7 \%$ dan setelah adanya tindakan $62,5 \%$. terjadi peningkatan kognitif sebesar $12,5 \%$ pada kemampuan mengklasifikasi, $12,5 \%$ pada kemampuan sebab-akibat sebesar $12,5 \%$ dan 20,8\% pada kemampuan memecahkan masalah.

Setelah dilakukan kegiatan sains melalui konstruktivisme inkuiri dengan metode eksperimen terjadi peningkatan kembali pada siklus I dan siklus II pada setiap kemampuan yaitu, kemampuan mengklasifikasi mengalami peningkatan 20,9\%, kemampuan menghubungkan sebab-akibat (meramalkan) mengalami 
peningkatan $16,7 \%$ dan kemampuan memecahkan masalah mengalami peningkatan yang cukup besar yaitu $25 \%$.

Berdasarkan pengamatan yang dilakukan bersama peneliti dan rekan guru, dapat dikemukakan bahwa pelaksanaan kegiatan sains melalui eksperimen yang diberikan oleh peneliti dan guru dapat meningkatkan kemampuan kognitif anak ini terbukti adanya peningkatan presentase antara sebelum adanya tindakan dan setelah adanya tindakan baik siklus I maupun siklus II.

Berdasarkan bukti yang ada dan data yang diperoleh selama penelitian berlangsung kemampuan kognitif anak kelas B mengalami peningkatan yang cukup signifikan, yaitu peningkatan dari aspek mengklasifikasi yaitu 58,3\% sebelum tindakan menjadi $70,8 \%$ di siklus I dan $97,7 \%$ pada siklus II. Kemampuan menghubungkan sebab akibat dari 50\%, menjadi $62,5 \%$ dan $79,2 \%$. Sementara pada kemampuan memecahkan masalah adalah sebesar $41,7 \%$ pada saat sebelum tindakan, $62,5 \%$ di siklus I dan meningkat kembali menjadi $87,5 \%$. Dari hasil yang didapat dapat disimpulkan bahwa penggunaan kegiatan sains dengan metode eksperimen efektiv meningkatkan kemampuan kognitif anak terbukti dapat meningkatkan kemampuan kognitif anak. Dengan didapatkannya hasil ini maka peneliti menghentikan penelitian ini hanya sampai siklus II karena sudah sesuai dengan hasil yang diharapkan oleh peneliti di awal penelitian.

Hasil yang diperoleh dalam penelitian ini menunjukkan bahwa dalam kemampuan mengklasifikasi pada anak kelompok B ini mengalami peningkatan. Anak mampu mengelompokkan biji-bijian dan boneka tidak bisa tidur sesuai dengan warnanya. Ini sesuai dengan teori dari California Infant/Toddler Learning \& Development Foundation bahwa anak mampu untuk mengurutkan, mengelompokkan dan menghubungkan benda sesuai dengan cirinya misalnya warna, bentuk dan ukuran. Kemampuan menghubungkan sebab akibat meningkat, setelah anak mampu memprediksi tentang percobaan yang akan dilakukan ini sesuai dengan teori yang berbunyi melalui pengembangan sebab akibat anak akan membangun kemampuan mereka untuk memecahkan masalah, untuk membuat prediksi dan untuk memahami dampak dari perilaku mereka terhadap orang lain atau pada suatu benda. Kemampuan memecahkan masalah meningkat setelah anak berhasil menemukan jawaban sendiri setelah anak melakukan percobaan, hal ini sesuai dengan teori yang berbunyi anak menunjukkan tingkat kemampuan kognitifnya ketika anak berhasil dalam memecahkan masalah. 
Dari hasil yang telah didapat setelah adanya penelitian ini, maka dapat terbukti dengan adanya kegiatan sains melalui eksperimen ini dapat meningkatkan aspek kognitif yaitu kemampuan mengklasifikasi, kemampuan menghubungkan sebab akibat dan kemampuan memecahkan masalah pada anak kelompok B di TK ABA Sumberadi. Jadi dalam kegiatan sains, akan melibatkan anak lebih aktif untuk menggunakan lima inderanya untuk melihat, mendengar, meraba, merasakan dan membau. Sementara permasalahan yang dikaji dalam penelitian ini adalah meningkatkan kemampuan kognitif siswa melalui kegiatan sains yang dipraktikan anak secara langsung, kurangnya peningkatan kemampuan kognitif anak melalui pembelajaran sains disebabkan oleh beberapa hal antara lain: Media yang digunakan oleh guru dalam penyampaian materi kegiatan sains kurang menarik sehingga anak kurang antusias. Serta tempat dan suasana kelas yang kurang memadai sehingga anak kurang leluasa dalam melakukan percobaan.

Untuk mengatasi masalah tersebut peneliti berusaha untuk melakukan suatu tindakan yang dapat membawa perbaikan dan peningkatan kemampuan kognitif anak melalui kegiatan sains. Dalam proses pembelajaran melalui kegiatan sains ini telah dibuktikan bahwa anak lebih antusias dan tertarik untuk memperhatikan materi yang telah disampaikan oleh guru. Anak lebih bersemangat dalam melakukan percobaan yang dilakukannya sendiri. Anak juga dapat mengasah ingatannya tentang langkah-langkah apa yang dilakukan dalam percobaan setelah anak mengamati demonstrasi yang dilakukan oleh guru. Kesalahan yang dilakukan anak juga sedikit karena anak memang tertarik untuk melakukan percobaan tersebut.

Penelitian ini telah membuktikan bahwa dengan kegiatan sains yang melalui konstruksi inkuiri dengan eksperimen dipraktikkan oleh anak dapat meningkatkan kemampuan kognitif anak di TK ABA Sumberadi. Peningkatan kemampuan kognitif anak dapat dilihat dari perolehan data sebelum adanya tindakan dan sesudah siklus I dan siklus II. Dari data masing-masing terlihat peningkatan kemampuan kognitif yang cukup berarti.

Kegiatan sains dapat dilakukan di dalam maupun di luar ruangan tergantung percobaan apa yang akan dilakukan. Selama kegiatan sains digunakan sebagai sarana meningkatkan kemampuan kognitif anak lebih terlihat antusias dalam melakukan percobaan yang dilakukan. 
Dari sisi guru terlihat adanya perubahan peran yang awalnya hanya sekedar pemberi informasi menjadi fasilitator yang memfasilitasi siswa dalam belajar dan mencari inisiatif untuk meningkatkan kemampuan kognitif melalui kegiatan sains.

Berdasarkan penelitian dan uraian diatas, menunjukkan bahwa penggunakan kegiatan sains dalam pembelajaran terbukti berhasil meningkatkan kemampuan kognitif anak kelompok B TK ABA Sumberadi. Hal tersebut dapat dilihat dari peningkatan yang dialami dalam penelitian yang dilakukan peneliti dari pra tindakan, siklus I sampai siklus II yaitu dari presentase kemampuan mengklasifikasi dari pra tindakan sebesar 58,3\%, kemudian pada siklus I meningkat menjadi $70,8 \%$ dan pada siklus II kembali meningkat menjadi $91,7 \%$. Sementara pada kemampuan menghubungkan sebab-akibat dari pra tindakan sebesar $50 \%$, kemudian pada siklus I meningkat menjadi $62,5 \%$ dan pada siklus II meningkat lagi menjadi $79,2 \%$. Kemampuan memecahkan masalah pada pra tindakan sebesar $41,7 \%$, meningkat di siklus I menjadi $62,5 \%$ dan meningkat kembali menjadi $87,5 \%$ pada siklus II.

Dengan melihat kelebihan dan kekurangan yang terjadi selama proses penelitian dapat disimpulkan bahwa penggunaan kegiatan sains dapat meningkatkan kemampuan kognitif anak kelompok B di TK ABA Sumberadi.

\section{Gambar dan Tabel}

Tabel 1.Instrumen Indikator Kemampuan

\begin{tabular}{|c|l|l|}
\hline No. & \multicolumn{1}{|c|}{ Indikator } & \multicolumn{1}{|c|}{ Deskripsi } \\
\hline 1. & $\begin{array}{l}\text { Mengklasifikasikan } \\
\text { benda berdasarkan } \\
\text { fungsinya }\end{array}$ & $\begin{array}{l}\text { a. Mengelompokkan benda sesuai dengan } \\
\text { warnanya } \\
\text { b. Mengurutkan urutan benda yang digunakan } \\
\text { pada saat eksperimen }\end{array}$ \\
\hline 2. & $\begin{array}{l}\text { Mengenal sebab- } \\
\text { akibat tentang } \\
\text { lingkungannya }\end{array}$ & $\begin{array}{l}\text { a. Memprediksi eksperimen yang dilakukan } \\
\text { b. Menceritakan secara urut langkah-langkah } \\
\text { eksperimen }\end{array}$ \\
\hline 3. & $\begin{array}{l}\text { Memecahkan } \\
\text { masalah sederhana }\end{array}$ & $\begin{array}{l}\text { a. Melakukan eksperimen dengan mandiri } \\
\text { b. Menemukan jawaban sendiri setelah } \\
\text { melakukan eksperimen }\end{array}$ \\
\hline
\end{tabular}

Tabel 2. Peningkatan Kognitif sebelum tindakan dan setelah tindakan

\begin{tabular}{|c|l|c|c|c|}
\hline No. & $\begin{array}{c}\text { Indikator } \\
\text { Kemampuan }\end{array}$ & $\begin{array}{c}\text { Presentase } \\
\text { kemampuan } \\
\text { sebelum } \\
\text { tindakan }\end{array}$ & $\begin{array}{c}\text { Presentase } \\
\text { kemampuan } \\
\text { setelah tindakan }\end{array}$ & $\begin{array}{c}\text { Peningkat } \\
\text { an } \\
\text { presentase }\end{array}$ \\
\hline 1. & Mengklasifikasi & $58,3 \%$ & $70,8 \%$ & $12,5 \%$ \\
\hline 2. & Menghubungkan & $50 \%$ & $62,5 \%$ & $12,5 \%$ \\
\hline
\end{tabular}




\begin{tabular}{|c|l|c|c|c|}
\hline s. & sebab-akibat & & & \\
\hline $\begin{array}{l}\text { Memecahkan } \\
\text { masalah }\end{array}$ & $41,7 \%$ & $62,5 \%$ & $20.8 \%$ \\
\hline
\end{tabular}

Tabel. 3 Peningkatan Presentase kemampuan Kognitif Siklus I dan Siklus II

\begin{tabular}{|c|l|c|c|c|}
\hline No. & \multicolumn{1}{|c|}{ Indikator Kemampuan } & $\begin{array}{c}\text { Presentase } \\
\text { siklus I }\end{array}$ & $\begin{array}{c}\text { Presentase } \\
\text { Siklus II }\end{array}$ & $\begin{array}{c}\text { Peningkatan } \\
\text { presentase }\end{array}$ \\
\hline 1. & Mengklasifikasi & $70,8 \%$ & $91,7 \%$ & $20,9 \%$ \\
\hline 2. & $\begin{array}{l}\text { Menghubungkan sebab- } \\
\text { akibat }\end{array}$ & $62,5 \%$ & $79,2 \%$ & $16,7 \%$ \\
\hline 3. & Memecahkan masalah & $62,5 \%$ & $87,5 \%$ & $25 \%$ \\
\hline
\end{tabular}

Tabel. 4 Perbandingan Presentase Peningkatan kemampuan Kognitif Sebelum Tindakan dan Sesudah Siklus I dan Siklus II

\begin{tabular}{|c|l|c|c|c|}
\hline No. & \multicolumn{1}{|c|}{ Aspek Penilaian } & $\begin{array}{c}\text { Sebelum } \\
\text { tindakan }\end{array}$ & $\begin{array}{c}\text { Presentase } \\
\text { siklus I }\end{array}$ & $\begin{array}{c}\text { Presentase } \\
\text { Siklus II }\end{array}$ \\
\hline 1. & Mengklasifikasi & $58,3 \%$ & $70,8 \%$ & $91,7 \%$ \\
\hline 2. & $\begin{array}{l}\text { Menghubungkan sebab- } \\
\text { akibat }\end{array}$ & $50 \%$ & $62,5 \%$ & $79,2 \%$ \\
\hline 3. & Memecahkan masalah & $41,7 \%$ & $62,5 \%$ & $87,5 \%$ \\
\hline
\end{tabular}

\section{SIMPULAN}

Berdasarkan hasil penelitian, diperoleh data bahwa kegiatan sains melalui eksperimen dapat meningkatkan kemampuan kognitif anak kelompok B di TK ABA Sumberadi. Hal tersebut dibuktikan dari peningkatan yang dialami dari siklus ke siklus, baik siklus I maupun siklus II yaitu nilai rata-rata kemampuan kognitif anak pada pratindakan adalah $50 \%$ kemudian meningkat setelah pelaksanaan siklus I menjadi 65,3\% dan meningkat lagi setelah pelaksanaan siklus II menjadi 86,1\%.

Berdasarkan penelitian diatas, untuk mencapai keberhasilan kegiatan sains di TK disarankan sebagai berikut, bagi Lembaga adalah memberikan arahan kepada guru-guru untuk menggunakan kegiatan sains dalam pembelajaran dan menyediakan fasillitas atau alat-alat yang menunjang guru untuk memberikan materi sains kepada perserta didik. Bagi Guru adalah agar guru dapat menggunakan kegiatan sains sebagai salah satu cara untuk meningkatkan kemampuan kognitif anak serta untuk menciptakan suasana belajar yang menyenangkan bagi peserta didik. 


\section{DAFTAR PUSTAKA}

Arikunto, Suharsimi, and Supardi Suhardjono. 2006. Penelitian Tindakan Kelas. Jakarta: Bumi Aksara.

Dimiyati Mujion. 2010. Belajar Pembelajaran. Bandung: Alfabeta.

Hamdani, Strategi Belajar Mengajar. 2011. Pustaka Setia Bandung: CV.

Hamruni. 2012. Strategi Pembelajaran. Yogyakarta: Insan Madani.

Khadijah. 2016. "Pengembangan Kognitif Anak Usia Dini."

Mulyasa, H E. 2012. Bandung: Remaja Rosdakarya Manajemen Paud.

Nur Hamzah. 2015. Pengembangan Sosial Anak Usia Dini. PONTIANAK: IAIN PONTIANAK PRESS.

Putri, Suci Utami. 2019. Pembelajaran Sains Untuk Anak Usia Dini. Sumedang: UPI Sumedang Press.

Roza, Mela Murti. 2012. "Pelaksanaan Pembelajaran Sains Anak Taman Kanak-Kanak Aisyiyah Bustanul Athfal 29 Padang." Jurnal Ilmiah Pesona PAUD 1(5).

Suryana, Dadan. 2016. Pendidikan Anak Usia Dini: Stimulasi \& Aspek Perkembangan Anak. Prenada Media.

Suryani, Nunuk, and Leo Agung. 2012. 212 Yogyakarta: Ombak Strategi Belajar Mengajar.

Susanto, Ahmad. 2012. Jakarta: Kencana Prenada Media Group Perkembangan Anak Usia Dini (Cet. 2).

Suwandi, Sarwiji. 2009. 13 Surakarta: Panitia Sertifikasi Guru Rayon Penelitian Tindakan Kelas (PTK) Dan Penulisan Karya IImiah.

Suyadi, M Pd I. 2010. "Psikologi Belajar PAUD." Yogyakarta: Pedagogia.

Yulianti, Dwi. 2010. Indeks Bermain Sambil Belajar Sains Di Taman Kanak-Kanak. Jakarta. 